\title{
Intimate-partner violence and its relationship with substance consumption by Mexican men and women: National Survey on Addictions
}

\author{
Guillermina Natera Rey, ${ }^{1}$ Midiam Moreno López, ${ }^{2}$ Filiberto Toledano-Toledano, ${ }^{2}$ Francisco Juárez García, \\ Jorge Villatoro Velázquez'
}

Dirección de Investigaciones Epidemiológicas y Psicosociales, Instituto Nacional de Psiquiatría Ramón de la Fuente Muñiz, Ciudad de México, México.

2 Hospital Infantil de México Federico Gómez, Ciudad de México, México.

Correspondence:

Guillermina Natera Rey

Instituto Nacional de Psiquiatría

Ramón de la Fuente Muñiz.

Calzada México-Xochimilco 101

Col. San Lorenzo Huipulco,

Tlalpan, 14370, Ciudad de México,

México

Email: naterar@imp.edu.mx

Received: 18 June 2020

Accepted: 9 October 2020

Citation:

Natera Rey, G., Moreno López, M., Toledano-Toledano, F., Juárez García, F., \& Villatoro Velázquez, J. (2021). Intimate-partner violence and its relationship with substance consumption by Mexican men and women: National Survey on Addictions. Salud Mental, 44(3), 135-143.

DOI: $10.17711 /$ SM.0185-3325.2021.018

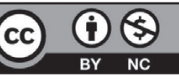

\begin{abstract}
Introduction. Research findings about intimate-partner violence (IPV) have focused mostly on women as victims of violence. Recent studies show the importance of violence inflicted by women towards men or between same-sex couples. Objective. To estimate the prevalence of intimate-partner violence and its association with alcohol and drug consumption in a representative sample of men and women in Mexico through secondary data analysis. Method. The data come from a representative sample who filled out the section on intimate-partner violence in the Mexican 2011 Encuesta Nacional de Adicciones (National Survey on Addictions). Results. The prevalence of intimate-partner violence in the last year was $17.6 \%$ against women and $13.4 \%$ against men. If one of the two partners consumed substances, the risk that men and women would experience violence increased, and that risk was even greater if both consumed. Discussion and conclusion. This is the first time violence against men was reported in a Mexican national study. The findings show that gender-based violence should also be considered a result of social and cultural violence.
\end{abstract}

Keywords: Intimate-partner violence, alcohol consumption, drug use, Mexico.

\section{RESUMEN}

Introducción. Los hallazgos de investigación sobre la violencia de pareja se han centrado principalmente en las mujeres como víctimas de la violencia. Estudios recientes destacan también la importancia de la violencia infligida por las mujeres hacia los hombres o entre parejas del mismo sexo. Objetivo. Estimar la prevalencia de la violencia de pareja y su asociación con el consumo de alcohol y drogas en una muestra representativa de hombres y mujeres en México mediante un análisis secundario de datos. Método. Los datos provienen de la Encuesta Nacional de Adicciones de México 2011, específicamente de una muestra representativa que contestó la sección sobre violencia de pareja. Resultados. La prevalencia de violencia de pareja en el último año fue de $17.6 \%$ hacia las mujeres y de $13.4 \%$ hacia los hombres. Si uno de los dos integrantes de la pareja consumía sustancias, aumentaba el riesgo de que hombres o mujeres experimentaran violencia y ese riesgo era aún mayor si ambos consumían. Discusión y conclusión. Esta es la primera vez que se reporta la violencia hacia los hombres en un estudio nacional mexicano. Los resultados muestran que la violencia de género también debe considerarse como resultado de la violencia social y cultural.

Palabras clave: Violencia de pareja, consumo de alcohol, consumo de drogas, México. 


\section{INTRODUCTION}

Research findings about intimate-partner violence (IPV) have focused mostly on women as victims of violence. However, recent studies show the importance of violence inflicted by women towards men or between same-sex couples (Carmo, Grams, \& Magalhães, 2011; Lövestad \& Krantz, 2012). In a multinational study coordinated by the World Health Organization (WHO), it was found that the percentage of women who had ever had partners and who had suffered IPV at any time ranged from $15 \%$ to $71 \%$ (WHO, 2005). A study of IPV between men and women in Portugal reported that, from the total number of victims who reported IPV between 2007 and 2009, 11.5\% were men (Carmo et al., 2011). In the United States, Coker et al. (2002) reported that $28.9 \%$ of women and $22.9 \%$ of men had been victims of IPV throughout their lives. Similarly, in 2011 it was reported that $35.6 \%$ of women and $28.5 \%$ of men had experienced IPV (Black et al., 2011). A multinational study in Latin America on gender equity that included men and women between 18 and 59 years of age in cities in Brazil, Chile, and Mexico showed that $28 \%$ of women in Brazil and $31 \%$ in Chile and Mexico reported having suffered physical violence at some time from their partners; in men, these percentages varied slightly more, $17 \%$ in Mexico, $24 \%$ in Brazil, and 31\% in Chile (Barker \& Aguayo, 2012).

Epidemiological research in Mexico (Instituto Nacional de Salud Pública [INSP], 2008) indicated that $43.9 \%$ of women aged 15 years or older have experienced partner violence at some point in life and $25.6 \%$ in the last 12 months. Regarding the associated factors, more violence, especially physical and sexual violence, is reported for those who have a lower level of education and lower economic income (Instituto Nacional de Estadística y Geografía [INEGI], 2017). Other studies report that economically active women, regardless of education or socioeconomic status, are more likely to suffer emotional, physical, and sexual violence (Instituto Nacional de las Mujeres [INMUJERES], 2008). Regarding age, Catalano (2012) has reported that violence towards men is more often from women aged 18-35.

Alcohol consumption and substance abuse by the perpetrator is an important risk factor and facilitator for IPV. Alcohol is the most researched substance and is reported to cause the greatest amount of damage (Brighton, Moxham, \& Traynor, 2016; Leonard \& Blane, 1992; O'Leary \& Schumacher, 2003). Psychological or physical aggression was two to three times higher when the perpetrator had drunk compared to the days he had not drunk (Moore, Elkins, McNulty, Kivisto, \& Handsel, 2011). Alcohol abuse has served as an excuse to justify or forgive violence (Leonard, 2005) and tends to mitigate the circumstances of aggression or to reduce sanctions (Tryggvesson, 2004). In addition, the belief that men are more likely to use alcohol to inhibit the expression of aggression and to report alcohol consumption as a coping mechanism of negative emotions is still present. Conversely, in certain social contexts, women are encouraged to internalize their emotions and to drink with moderation (Catalano, 2012; Choo et al., 2014).

Even though alcohol abuse is the main problem of consumption in Mexico (Medina-Mora, Real, Villatoro, \& Natera, 2013), drug use is increasingly visible, and socially, there is greater acceptance towards its consumption (Villatoro-Velázquez et al., 2012). A nationwide survey found that a woman was 15 times as likely to be raped by her partner when he consumed drugs than when he consumed alcohol, which risk was 3.2 times greater than in cases without substance consumption (Natera \& Juárez, 2010).

Regarding the context of IPV, the place where women experience the most violence is at home (Miranda, Halperin, Limón, \& Tuñon, 1998). Between 55\% and 95\% of women who have been victims of physical violence acknowledged that they had never sought help from official services (WHO, 2005). In Mexico, almost $80 \%$ of women who suffered physical or sexual violence from their current partner did not request support and did not file a complaint (INEGI, 2017).

Although surveys in Mexico and previous studies (INEGI, 2017; INEGI \& INMUJERES, 2013) have revealed epidemiological data on violence against women, there is still no national study that includes men, nor the population of 12 to 65 years living in their homes. Therefore, the objective of this epidemiological study was to estimate the prevalence of IPV and its association with alcohol and drug consumption, in a representative sample of men and women in Mexico, through secondary data analysis.

\section{METHOD}

The data from this study come from the 2011 Encuesta Nacional de Adicciones (ENA, National Survey on Addictions). The description of the methodology of the survey has been published in other studies (Villatoro-Velázquez et al., 2012). Key features are described below. It is a household survey with national representation that includes people aged 12 to 65 who live in rural and urban areas. The design of the sample was probabilistic, stratified with cluster selection in various sampling stages. The response rate at the national level was $73.3 \%$.

For the purposes of this secondary data analysis, the population that had a partner at the time of the interview was included $(n=11,096)$. There were no other eligibility criteria in this section.

\section{Instruments}

The instrument used in ENA 2011 is a standardized questionnaire used systematically in previous studies and is answered through a direct interview on a computerized version. 


\section{Intimate partner violence scale}

The Intimate Partner Violence Scale has been validated in the Mexican population by Natera Rey, Juárez García, and Tiburcio Sainz (2004). It includes nine items for men and 10 items for women. It asks if, in their lives and in the past 12 months, they had experienced any of the following IPV: Has your partner shouted at you, insulted you, or humiliated you; has threatened to beat you; has beaten you; controls or has controlled most of your activities; manifests his/her jealousy by beating, insulting, humiliating you, or controlling your activities; has forced you to have sexual relations; has threatened to kill you; if he/she threatened to kill you, do you believe he/she is capable of doing so?; has threatened to commit suicide or has attempted it; and have you been beaten by your partner when you were pregnant (question only for women). A Cronbach's alpha reliability score of .70 was obtained for men and .81 for women.

\section{Other variables: marital status and substance use}

Marital status. The population that said in the sociodemographic data section the options: married, widowed, divorced, separated, were classified as married or once married.

Substance use. a) Consumption of alcohol or drugs corresponded to the prevalence of each substance at some point in life. b) The couple's consumption of substances corresponded to the consumption of alcohol or drugs sometime in the life of the person who answered the questionnaire and reported the consumption of alcohol or drugs by their current partner. There were three options for each substance (alcohol or drugs): 1. neither the interviewee nor his/her partner had ever consumed; 2 . one of the two consumed; and 3. both consumed. Finally, c) to learn about consumption in the event of violence, the following question was asked: In some of the events mentioned, 1) Was alcohol consumed? 2) Were drugs used? and 3) Were alcohol and drugs used at the same time? For each of these three questions, the response options were 1) You, 2) Your partner, 3) Both, and 4) Neither. For this study, options 1 to 3 were grouped, leaving dichotomous variables for each type of consumption.

Context and seeking help. Regarding the context, the questionnaire asked about the place where the incident occurred, whether they thought about separating from their partner, and whether they sought professional help.

\section{Statistical analysis}

The overall prevalence of violence at any time and in the last year was calculated by sex, with $95 \%$ confidence intervals $(95 \% \mathrm{CI})$. Subsequently, 95\% CIs were calculated to analyze the sociodemographic characteristics of the popu- lation that reported IPV by sex. Likewise, for the bivariate analysis, the chi-squared test was applied to find the differences by sex and the characteristics of the situation in which each reported incident of violence occurred. Kaplan-Meier curves and Cox regressions were generated to calculate the probabilities of the onset of violence, alcohol consumption, and drug use. Finally, to obtain the factors related to violence with the current partner in the last year, logistic regression models were performed, stratified by sex, yielding odds ratios (ORs) with 95\% CIs. The analyses were done in STATA Version 13 (2013) and were adjusted by the design of the survey using the command "SVY." Normalized weighting was used to perform the analyses $(n=11,096)$, and the population was weighted to draw the frequency tables $(N=54,370,267)$ (Figure 1). For more specific data of the sample size calculation, it is suggested to consult the ENA 2011 report (Villatoro-Velázquez et al., 2012).

\section{Ethical considerations}

The research was approved by the Ethics Committee of the Instituto Nacional de Psiquiatría Ramón de la Fuente Muñiz (INPRFM, National Institute of Psychiatry). All participants were read an informed consent letter or assent in the case of adolescents, and information was collected only from those who agreed to participate.

\section{RESULTS}

\section{Prevalence of IPV}

Of the total sample, $50.8 \%$ were 35 to 65 years old, $80 \%$ were married or lived in a domestic partnership, $27.6 \%$ had an elementary education level or lower, $31 \%$ were home-

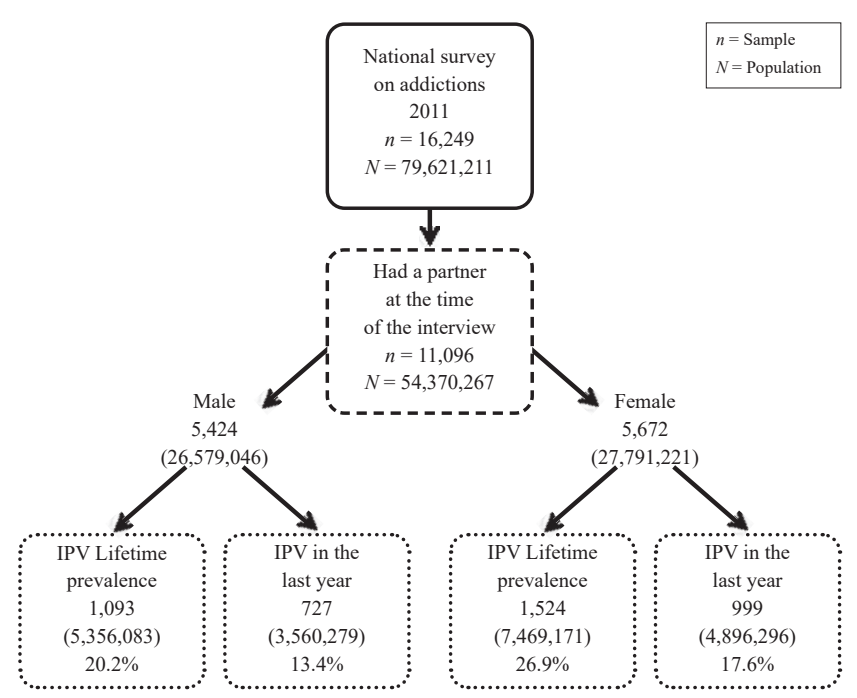

Figure 1. Flow diagram of sample selection process. 
Table 1

Prevalence of Intimate-Partner Violence by sex. 2011 National Survey on Addictions

\begin{tabular}{|c|c|c|c|c|c|c|c|c|c|}
\hline & \multicolumn{3}{|c|}{$\begin{array}{c}\text { Men } \\
(N=26,579,046) \\
\end{array}$} & \multicolumn{3}{|c|}{$\begin{array}{c}\text { Women } \\
(N=27,791,221)\end{array}$} & \multicolumn{3}{|c|}{$\begin{array}{c}\text { Total } \\
(N=54,370,267) \\
\end{array}$} \\
\hline & $N$ & $\%$ & $95 \% \mathrm{Cl}$ & $N$ & $\%$ & $95 \% \mathrm{Cl}$ & $N$ & $\%$ & $95 \% \mathrm{Cl}$ \\
\hline \multicolumn{10}{|l|}{ IPV Lifetime } \\
\hline Physical and verbal violence & $5,346,379$ & 20.1 & $18.1-22.1$ & $7,407,696$ & 26.7 & $24.9-28.4$ & $12,754,075$ & 23.5 & $22.1-24.8$ \\
\hline Threat of death and suicide & 261,775 & 1.0 & $.6-1.4$ & 882,325 & 3.2 & $2.5-3.9$ & $1,144,100$ & 2.1 & $1.7-2.5$ \\
\hline Any type of violence & $5,356,083$ & 20.2 & $18.2-22.2$ & $7,469,171$ & 26.9 & $25.0-28.6$ & $12,825,254$ & 23.6 & $22.2-24.9$ \\
\hline \multicolumn{10}{|l|}{ IPV in the last year } \\
\hline Physical and verbal violence & $3,544,695$ & 13.3 & $11.5-15.1$ & $4,842,592$ & 17.4 & $15.9-19.0$ & $8,387,287$ & 15.4 & $14.2-16.7$ \\
\hline Threat of death and suicide & 157,736 & .6 & $.1-.5$ & 497,277 & 1.8 & $.6-1.2$ & 655,013 & 1.2 & $.4-.8$ \\
\hline Any type of violence & $3,560,279$ & 13.4 & $11.6-15.2$ & $4,896,296$ & 17.6 & $16.2-19.3$ & $8,456,576$ & 15.6 & $14.4-16.9$ \\
\hline \multicolumn{10}{|l|}{ In the last year, your current partner... ${ }^{a}$} \\
\hline Has shouted, insulted, or humiliated you & $2,970,797$ & 11.2 & $9.5-12.8$ & $4,035,605$ & 14.5 & $13.1-15.9$ & $7,006,401$ & 12.9 & $11.8-14.0$ \\
\hline Has threatened to beat you & 540,434 & 2.0 & $1.5-2.6$ & $1,294,297$ & 4.7 & $3.9-5.4$ & $1,834,731$ & 3.4 & $2.9-3.8$ \\
\hline Has beat you & 355,050 & 1.3 & $.9-1.8$ & 592,532 & 2.1 & $1.7-2.6$ & 947,582 & 1.7 & $1.4-2.1$ \\
\hline $\begin{array}{l}\text { Controls or has controlled most of your } \\
\text { activities }\end{array}$ & 941,517 & 3.5 & $2.8-4.3$ & $1,511,036$ & 5.4 & $4.6-6.3$ & $2,452,553$ & 4.5 & $3.9-5.1$ \\
\hline $\begin{array}{l}\text { Manifests his/her jealousy by beating, } \\
\text { insulting, humiliating, or controlling } \\
\text { your activities }\end{array}$ & 905,616 & 3.4 & $2.5-4.3$ & $1,161,172$ & 4.2 & $3.5-4.9$ & $2,066,789$ & 3.8 & $3.2-4.4$ \\
\hline $\begin{array}{l}\text { Have you been beaten by your partner } \\
\text { when you were pregnant? }\end{array}$ & - & - & - & 60,963 & .2 & $.0-.4$ & - & - & - \\
\hline Has forced you to have sex & 60,373 & .2 & $.0-.5$ & 316,312 & 1.1 & $.8-1.5$ & 376,684 & .7 & $.5-.9$ \\
\hline Has threatened to kill you & 73,485 & .3 & $.1-.5$ & 256,356 & .9 & $.6-1.2$ & 329,841 & .6 & $.4-.8$ \\
\hline $\begin{array}{l}\text { If he/she has threatened to kill you, do you } \\
\text { believe he/she is capable of doing so? }\end{array}$ & 16,708 & .1 & $.0-.1$ & 140,507 & .5 & $.3-.7$ & 157,215 & .3 & $.2-.4$ \\
\hline $\begin{array}{l}\text { Has threatened to commit suicide or } \\
\text { has attempted it }\end{array}$ & 91,904 & .3 & $.1-.6$ & 301,044 & 1.1 & $.7-1.5$ & 392,948 & .7 & $.5-1.0$ \\
\hline
\end{tabular}

a Percentages obtained from the total population that reported having a partner currently by sex.

makers, $52.2 \%$ had a monthly family income of up to two minimum wages (30 USD per day), and $22 \%$ lived in a rural community.

The prevalence of IPV at some point in life in the general population was $23.6 \%$. It was higher in women $(26.9 \% ; 95 \%$ CI $[25.0,28.6])$ than in men $(20.2 \% ; 95 \%$ CI $[18.2,22.2])$. For violence in the last year with the current partner, the prevalence overall was $15.6 \%$, in women $17.6 \%$, and in men $13.4 \%$ (Table 1 ).

In the last year, shouting, insults, or humiliation were the most prevalent events, at $14.5 \%$ in women and $11.2 \%$ in men, a significant difference. Some $4.5 \%$ responded that their partner controlled most of their activities, and a greater proportion in women $(5.4 \%)$ than men $(3.5 \%)$ said this. Other events where a greater prevalence was found for women were threats of beatings (women $4.7 \%$, men $2.0 \%$ ), death threats (women .9\%, men .3\%) and threats of suicide (women $1.1 \%$, men .3\%) (Table 1).

Table 2 shows the distribution of the population that reported IPV in the last year. This population was similar to the distribution of the general population. The groups with the highest proportion were those aged 18 years or older, married or once married, with less than a bachelor's degree, with an income of up to six minimum wages (approximately 600.00 dlls), and living in an urban community. Additionally, of the general population who reported having experienced IPV in the last year, $87.8 \%$ had used alcohol at some time (men $97.6 \%$; women $80.7 \%$ ), and $15.6 \%$ reported having used drugs at some point in their lives (men $30.8 \%$; women $4.5 \%$ ) (Table 2).

\section{Context of IPV and seeking professional help}

As shown in Table 3, IPV occurred most frequently at home (86.9\% men and $85.2 \%$ women), but significant differences were found by sex when the event occurred in the home of another person (men 6.4\%, women $9.2 \%$ ) and in a bar, club, or restaurant (men .6\%, women $2.5 \%$ ).

A total of $46.7 \%$ of women and $27.7 \%$ of men mentioned that violence occurred when both partners had consumed alcohol. Additionally, 5.1\% of men and 5.0\% of women reported that they or their partner had used drugs when the event of violence occurred.

Regarding the seeking of professional help, 34.4\% of women and $22.3 \%$ of men thought of separating from their current partner after they had a violent episode, and $8.8 \%$ 
Table 2

Characteristics of the Population that Reported Intimate-Partner Violence in the Last Year, According to Men and Women. 2011 National Survey on Addictions

\begin{tabular}{|c|c|c|c|c|c|c|c|c|c|}
\hline & \multicolumn{3}{|c|}{ Men } & \multicolumn{3}{|c|}{ Women } & \multicolumn{3}{|c|}{ Total } \\
\hline & $N$ & $\%$ & $95 \% \mathrm{Cl}$ & $N$ & $\%$ & $95 \% \mathrm{Cl}$ & $N$ & $\%$ & $95 \% \mathrm{Cl}$ \\
\hline \multicolumn{10}{|l|}{ Age of the subject } \\
\hline $35-65$ & $1,716,224$ & 48.2 & $42.8-53.6$ & $2,364,790$ & 48.3 & $43.8-52.8$ & $4,081,014$ & 48.3 & $44.7-51.8$ \\
\hline $18-34$ & $1,710,025$ & 48.0 & $42.5-53.6$ & $2,304,478$ & 47.1 & $42.6-51.6$ & $4,014,503$ & 47.5 & $43.8-51.2$ \\
\hline 12 to 17 & 134,031 & 3.8 & $2.4-5.9$ & 227,028 & 4.6 & $3.3-6.6$ & 361,059 & 4.3 & $3.2-5.6$ \\
\hline \multicolumn{10}{|l|}{ Marital Status $^{a}$} \\
\hline Single & 505,479 & 14.2 & $10.5-19.0$ & 387,021 & 7.9 & $5.2-11.9$ & 892,500 & 10.6 & $8.2-13.4$ \\
\hline Married or once married & $3,054,800$ & 85.8 & $81.0-89.5$ & $4,509,276$ & 92.1 & $88.1-94.8$ & $7,564,076$ & 89.4 & 86.6-91.8 \\
\hline \multicolumn{10}{|l|}{ Level of studies } \\
\hline Bachelor's degree or more & 480,157 & 13.6 & $10.3-17.9$ & 501,034 & 10.4 & $7.6-14.2$ & 981,191 & 11.8 & $9.5-14.5$ \\
\hline High school or equivalent & 878,100 & 24.9 & $20.4-30.1$ & 975,981 & 20.3 & $17.1-24.0$ & $1,854,080$ & 22.3 & $19.5-25.3$ \\
\hline Middle school & $1,231,335$ & 34.9 & $29.2-41.2$ & $1,936,811$ & 40.3 & $35.8-45.0$ & $3,168,146$ & 38.0 & $34.5-41.7$ \\
\hline None/Elementary & 937,072 & 26.6 & $21.3-32.6$ & $1,388,427$ & 28.9 & $25.2-33.0$ & $2,325,500$ & 27.9 & $24.8-31.3$ \\
\hline \multicolumn{10}{|l|}{ Labor situation } \\
\hline Does not work & 439,212 & 12.3 & $9.5-15.8$ & 368,733 & 7.5 & $5.1-11.1$ & 807,946 & 9.6 & $7.6-11.9$ \\
\hline Is dedicated to the home & 45,574 & 1.3 & $.4-4.4$ & $3,001,253$ & 61.3 & $56.9-65.5$ & $3,046,827$ & 36.0 & $32.6-39.6$ \\
\hline Works & $3,075,493$ & 86.4 & $82.6-89.5$ & $1,526,310$ & 31.2 & $27.5-35.1$ & $4,601,803$ & 54.4 & $50.8-58.0$ \\
\hline \multicolumn{10}{|l|}{ Family monthly income } \\
\hline More than 6 minimum wages & 282,364 & 8.9 & $5.5-14.0$ & 186,648 & 4.5 & $2.8-7.3$ & 469,012 & 6.4 & $4.5-9.0$ \\
\hline From 3 to 6 minimum wages & $1,428,056$ & 44.8 & $39.2-50.5$ & $1,213,874$ & 29.4 & 25.4-33.8 & $2,641,929$ & 36.1 & $32.5-39.9$ \\
\hline Up to 2 minimum wages & $1,478,574$ & 46.4 & $40.2-52.6$ & $2,725,089$ & 66.1 & $61.3-70.5$ & $4,203,663$ & 57.5 & $53.3-61.5$ \\
\hline \multicolumn{10}{|c|}{ Type of population where he/she lives } \\
\hline Rural & 649,403 & 18.2 & $13.6-24.1$ & $1,102,172$ & 22.5 & $17.6-28.4$ & $1,751,576$ & 20.7 & $16.6-25.6$ \\
\hline Urban & $2,910,876$ & 81.8 & $75.9-86.4$ & $3,794,124$ & 77.5 & $71.6-82.4$ & $6,705,000$ & 79.3 & $74.4-83.4$ \\
\hline \multicolumn{10}{|c|}{ Consumption of alcohol by the respondent } \\
\hline No & 86,415 & 2.4 & $1.4-4.3$ & 943,834 & 19.3 & $16.1-23.0$ & $1,030,248$ & 12.2 & 10.1-14.6 \\
\hline Yes & $3,473,864$ & 97.6 & $95.7-98.9$ & $3,952,463$ & 80.7 & $77.0-83.9$ & $7,426,327$ & 87.8 & 85.4-89.9 \\
\hline \multicolumn{10}{|l|}{ Drug use by the respondent } \\
\hline No & $2,462,670$ & 69.2 & $63.5-74.3$ & $4,677,433$ & 95.5 & $93.5-97.0$ & $7,140,103$ & 84.4 & $86.7-86.9$ \\
\hline Yes & $1,097,609$ & 30.8 & $25.7-36.5$ & 218,864 & 4.5 & $3.0-6.5$ & $1,316,473$ & 15.6 & $13.1-18.4$ \\
\hline
\end{tabular}

a Percentages were obtained within each sex, out of the population that has a current partner and reported IPV in the last year.

of women and 5.1\% of men sought professional help several times.

\section{Factors associated with IPV}

Regarding the factors associated with IPV in the last year (Table 4), it was found that men aged 18 to 34 years $(\mathrm{OR}=$ $1.4 ; 95 \% \mathrm{CI}[1.0,1.9])$, those currently or ever married (OR $=2.2 ; 95 \% \mathrm{CI}[1.3,3.8])$, and those living in urban communities $(\mathrm{OR}=1.5 ; 95 \% \mathrm{CI}[1.1,2.1])$ were more likely to suffer violence from their partner. The men also reported that if one of the members of the couple consumed alcohol, their risk of suffering violence was 4.6 times higher than when alcohol was not consumed, and this increased to 10.7 times if both consumed alcohol. If one of the two partners used drugs, the risk of men experiencing violence increased 1.5 times, and if both consumed, this risk increased 6.8 times.
In the case of women, the ones who were more likely to suffer violence by their partner, were those between 12 and 17 years $(\mathrm{OR}=2.0 ; 95 \% \mathrm{CI}[1.1,3.7])$, those who were married or ever married ( $\mathrm{OR}=4.8 ; 95 \% \mathrm{CI}[2.8,8.2])$, and those with the lowest salaries (OR $=1.9 ; 95 \%$ CI [1.1, 3.4]). In women, alcohol consumption by their partner increased the risk 2.1-fold, and alcohol consumption by both increased it 3.9-fold. The risk of experiencing violence also increased when one or both partners used drugs (ORs $=2.7$ and 6.9 , respectively).

Finally, the results of the probability analysis of the initiation of IPV showed that the lowest age of onset of $I P V$ was 11 years for men and women, although it had a faster growth in women than men with increasing age $(\mathrm{OR}=1.567, p<.001)$. On the other hand, the lowest age of onset for drug use by sex was reported at six years in women and at eight years in men, and the probability that 
Table 3

Context of Intimate-Partner Violence and Seeking Help

\begin{tabular}{|c|c|c|c|c|c|}
\hline & \multicolumn{2}{|c|}{ Men } & \multicolumn{2}{|c|}{ Women } & \multirow[b]{2}{*}{$X^{\prime a}$} \\
\hline & $N$ & $\%$ & $N$ & $\%$ & \\
\hline \multicolumn{6}{|l|}{ During the event of violence... } \\
\hline \multicolumn{6}{|l|}{ Where did it happen? } \\
\hline At home & $3,094,580$ & 86.9 & $4,172,038$ & 85.2 & $p=.303$ \\
\hline In the house of another person & 226,565 & 6.4 & 451,812 & 9.2 & $p=.030$ \\
\hline In a bar, club, tavern, or restaurant & 20,052 & 6 & 121,109 & 2.5 & $p=.005$ \\
\hline In the street or public transportation & 259,675 & 7.3 & 402,891 & 8.2 & $p=.492$ \\
\hline \multicolumn{6}{|l|}{ They had consumed ... } \\
\hline Alcohol & 985,086 & 27.7 & $2,281,515$ & 46.7 & $p<.001$ \\
\hline Drugs & 179,995 & 5.1 & 245,743 & 5.0 & $p=.937$ \\
\hline Alcohol and drugs & 147,830 & 4.2 & 189,386 & 3.9 & $p=.808$ \\
\hline \multicolumn{6}{|l|}{ After the event ... } \\
\hline \multicolumn{6}{|l|}{$\begin{array}{l}\text { Did you get separated or think of separating } \\
\text { from your current partner? }\end{array}$} \\
\hline I have thought of doing it & 792,593 & 22.3 & $1,685,887$ & 34.4 & $p<.001$ \\
\hline Yes, but I got back together with him/her & 782,433 & 22.0 & $1,598,647$ & 32.7 & \\
\hline \multicolumn{6}{|l|}{$\begin{array}{l}\text { Did you seek help from a doctor, nurse, para- } \\
\text { medic, or other health care professional? }\end{array}$} \\
\hline Yes, only once & 199,952 & 5.6 & 341,585 & 7.0 & $p=.005$ \\
\hline Yes, several times & 181,973 & 5.1 & 432,793 & 8.8 & \\
\hline
\end{tabular}

a Level of significance $<.05$

drug use had a faster growth in men than women with increasing age $(\mathrm{OR}=4.852, p<.001)$. The age of onset of alcohol consumption was six years for both; however, men had a faster increase in the likelihood of starting and maintaining alcohol consumption with increasing age $(\mathrm{OR}=2.121, p<.001)$. The growth rate in the likelihood of initiating alcohol consumption was the fastest, followed by being a victim of IPV and drug use (Figure 2).

\section{DISCUSSION AND CONCLUSION}

This is one of the first epidemiological studies in Mexico to record violence not only towards women but also towards men living with their partners. It is a national panorama between both sexes, in both rural and urban areas, a first approach was made at ENA 2008 (Natera \& Juárez, 2010). Violence against women continues to be significantly more common, although in these data from 2011, a lower percentage was obtained, 26.9\%, than in a similar survey in 2008 (Natera \& Juárez, 2010) that found that $46 \%$ of the women had experienced violence from their partner at some point in life. National surveys have mainly evaluated IPV against women, which has seen a reduction from $39.2 \%$ in 2006 to $27.3 \%$ in 2011 (INEGI \& INMUJERES, 2013). These figures encompass the estimate that, on average, approximately $35 \%$ of women have suffered violence (physical or sexual) by their partner or a third party in Mexico (WHO, 2017). In the present study, one in five men had been the victim of IPV, in contrast with one in four women.

We do not know why IPV decreased from 2008 to 2011, althougt the scale used was the same and the methods were similar. One answer could be that there has been more information in the media that violence is a problem to be denounced, and the health sector is promoting mechanisms to prevent violence against women and encouraging the creation of health care centers, though these are still not enough. The General Law for Access to Women to a Life Free of Violence has also been promoted (Diario Oficial de la Federación, 2007), which defines domestic violence against women as a crime. It is also possible that social movements, such as feminist movements, have had an influence in empowering women to defend themselves and protect themselves from violence, and in turn, it is possible that men are responding to these changes.

However, it seems that these social changes have not had enough impact on the youngest. Strikingly, we found a significant prevalence of violence in young people aged 12 to 16 years. This change in landscape, intimate relationships, or sexual life is increasingly found at earlier ages (Saldívar, 2018), which makes it a group at risk of following patterns of generalized violence in adult life. It is important for prevention to emphasize the promotion of conflict resolution without violence and the effects that substance use can have on violent behavior among young people.

When comparing the curves of the onset of violence, drug consumption, or alcohol consumption, we observed 
Table 4

Factors Associated with Intimate-Partner Violence in Men and Women. Mexico 2011

\begin{tabular}{|c|c|c|c|c|}
\hline & \multicolumn{4}{|c|}{ Violence in the last year } \\
\hline & \multicolumn{2}{|c|}{ Men } & \multicolumn{2}{|c|}{ Women } \\
\hline & OR & $95 \% \mathrm{Cl}$ & OR & $95 \% \mathrm{Cl}$ \\
\hline \multicolumn{5}{|l|}{ Age } \\
\hline 35 to 65 & 1.0 & - & 1.0 & - \\
\hline 18 to 34 & $1.4^{\mathrm{a}}$ & $1.0-1.9$ & 1.1 & $.9-1.4$ \\
\hline 12 to 17 & 1.5 & $.7-3.2$ & $2.0^{\mathrm{a}}$ & $1.1-3.7$ \\
\hline \multicolumn{5}{|l|}{ Marital status } \\
\hline Single & 1.0 & - & 1.0 & - \\
\hline Married or ever married & $2.2^{\mathrm{a}}$ & $1.3-3.8$ & $4.8^{\mathrm{a}}$ & $2.8-8.2$ \\
\hline \multicolumn{5}{|l|}{ School level } \\
\hline Bachelor's degree or more & 1.0 & - & 1.0 & - \\
\hline Highschool or equivalent & 1.2 & $.7-1.8$ & 1.3 & $.9-2.0$ \\
\hline Middle school & 1.2 & $.7-2.0$ & 1.3 & $.9-2.1$ \\
\hline None or Elementary & 1.3 & $.8-2.1$ & 1.3 & $.9-2.0$ \\
\hline \multicolumn{5}{|l|}{ Labor situation } \\
\hline Does not work & 1.0 & - & 1.0 & - \\
\hline Is dedicated to the home & 3.8 & $.9-15.6$ & .8 & $.5-1.3$ \\
\hline Works & 1.2 & $.8-1.9$ & 1.0 & $.6-1.6$ \\
\hline \multicolumn{5}{|l|}{ Family monthly income } \\
\hline More than 6 minimum wages & 1.0 & - & 1.0 & - \\
\hline From 3 to 6 minimum wages & .9 & $.5-1.6$ & 1.1 & $.6-1.9$ \\
\hline Up to 2 minimum wages & 1.1 & $.6-2.3$ & $1.9^{\mathrm{a}}$ & $1.1-3.4$ \\
\hline \multicolumn{5}{|l|}{$\begin{array}{l}\text { Type of population where he/ } \\
\text { she lives }\end{array}$} \\
\hline Rural & 1.0 & - & 1.0 & - \\
\hline Urban & $1.5^{\mathrm{a}}$ & $1.1-2.1$ & 1.1 & $.8-1.5$ \\
\hline \multicolumn{5}{|l|}{ Couple's alcohol consumption } \\
\hline None consumes & 1.0 & - & 1.0 & - \\
\hline 1 of the 2 consumes & $5.6^{\mathrm{a}}$ & $2.5-12.9$ & $3.1^{\mathrm{a}}$ & $2.0-4.7$ \\
\hline Both consume & $11.7^{\mathrm{a}}$ & $4.9-27.7$ & $4.9^{\mathrm{a}}$ & $3.2-7.5$ \\
\hline \multicolumn{5}{|l|}{ Couple's drug use } \\
\hline None consumes & 1.0 & - & 1.0 & - \\
\hline 1 of the 2 consumes & $2.5^{\mathrm{a}}$ & $1.8-3.5$ & $2.7^{\mathrm{a}}$ & $1.7-4.2$ \\
\hline Both consume & $7.8^{\mathrm{a}}$ & $1.7-36.9$ & $6.9^{\mathrm{a}}$ & $2.5-19.3$ \\
\hline
\end{tabular}

a Level of significance $<.05$.

that the latter began at younger ages, was more prevalent in men than in women, grew with age more rapidly than drugs. This indicates that alcohol consumption is one of the highest-risk substances at early ages. IPV grew less rapidly, the age of initiation is at 11 years of age and, above all, it was mostly directed at women.

We know (Esquivel-Santoveña \& Dixon, 2012; Stalans \& Ritchie, 2008) that alcohol and drugs are factors that are constantly present in IPV towards women and men. This study showed the same. We found that when both drugs and alcohol were used, violence increased homogenously for both sexes.

While it cannot be concluded that the consumption of alcohol and drugs causes IPV, associations are import- ant and are sufficient reasons to include the prevention of drug and alcohol abuse in interventions to prevent IPV. On the other hand, the perceived risk of the influence of the consumption of substances on violent behaviors differs between men and women: Men perceive a higher risk of violence when there is alcohol consumption by either one or both members of the couple, and women perceive a lower risk of violence if both have consumed, but not if only one consumes them. Here, women's perception is that if both of them are intoxicated with drugs, depending on the type of drug, violence will not necessarily be generated. The percentage of drug use in general was so low that it did not allow a distinction by type of drug for the partner-violence variable (Natera \& Hernández, 2013), although marijuana was the most consumed.

IPV varied with age. The fact that males aged 18-34 report being the most abused by women leads them to think that because they are young, they are living in a seemingly more open environment of gender equality, even where men accept and report being abused by women, leaving aside cultural aspects of "machismo."

The causes of violence against women have been studied (Muñoz \& Echeburúa, 2016). However, the causes or motives of violence by women towards men have not been studied; it has been presupposed that this occurs as a reactive response of women to men's violence or is bilateral. The exact reasons will be important to study.

Regarding the differences between urban and rural populations, we observed that in the urban population, the risk of violence by men tended to be greater; however, more alcohol is consumed in rural populations, which explains much of the IPV, while the consumption of drugs was considerably lower. Women consumed less in rural areas, and the consumption of drugs or alcohol in women in Mexico is perceived as a greater transgression in rural areas than in urban areas (Natera, 2017).

Despite the controversies that may exist about gender-based violence in that internationally, women have almost always been reported as victims, there is no denying that, increasingly, men are the victims of social violence, especially perpetrated by their partners (Carmo et al., 2011). This leads us to consider the problem of IPV not only as a matter of gender but also as a social and cultural problem that needs to be addressed from this perspective.

In Mexico, the cultural mandate that women should tolerate men's consumption of alcohol, including drunkenness, is associated with the machismo part of men's identity and the accepting or tolerating part of women's identity (Natera \& Holmila, 1990), which have resulted in the justification and legitimization of violence linked to alcohol consumption by men and emphasized submission and tolerance by women, leading the problem of violence to be kept hidden when there is substance use and discouraging the woman from asking for help (Natera \& Hernández, 2013). 

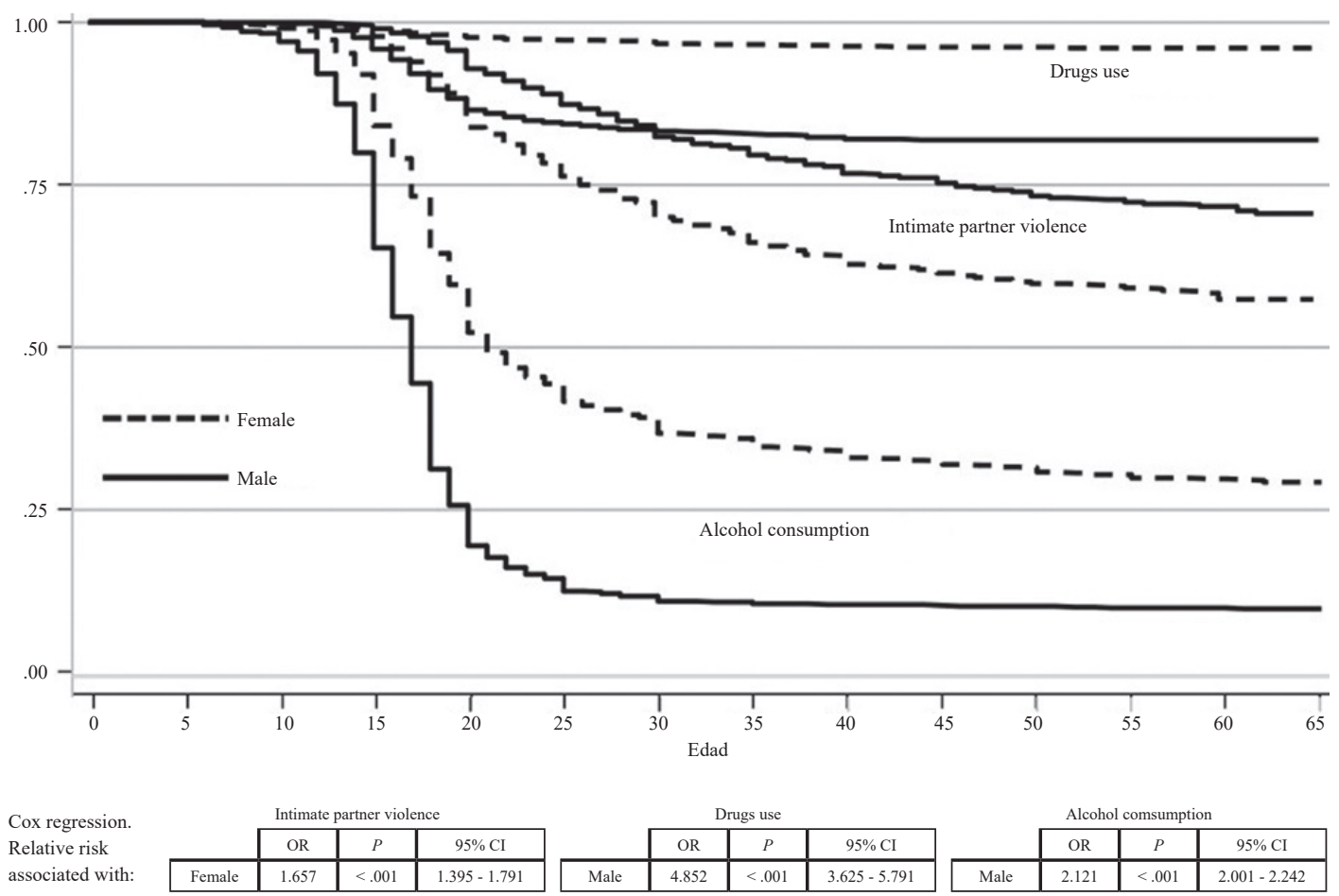

Figure 2. Probabilities associated with the onset of intimate partner violence, onset of drug use and onset of alcohol consumption by sex.

As observed in this study, a low percentage $(10.7 \%$ men and $15.8 \%$ women) requested help, and the help was mostly sought from the health care sector, where a woman can obtain legal support if she wishes to report. If the injuries are serious and endanger the life of the woman, the attending physician is obligated to report the perpetrator. Although male power is ceasing to be globally hegemonic (WHO, 2005), in our country, there is still great inequality; men have the right to correct female behavior and to make themselves feel socially superior in the home, in private places, and in public environments such as in restaurants and bars, where violence can occur. However, in this study, it is in the public context where women exerted greater violence towards men, which could be interpreted as a response of self-affirmation of women to an act of masculine (macho) violence and because they perceive being more protected in public spheres. However, the home continues to be the main arena for settling disputes.

It is clear that more explanatory factors of violence towards both men and women must be found, such as the influence of social determinants, not only the consumption of substances. Prevention should pay attention to the dynamics of the beginning of the consumption of substances at increasingly younger ages, especially alcohol in the youngest.

This study has an epidemiological basis: the problem of IPV and the use of substances at the national level. Fu- ture studies should inform us more precisely about the act of violence, amount of consumption per occasion, the type of drug, the reasons for gender-based violence at different ages and the type of relationship, as well as the reasons why victims did or did not seek help or report the violence. In addition, they should investigate the impact or results of the actions carried out by both civil and governmental organizations to reduce IPV at the national level and its association with substance abuse. Both quantitative and qualitative studies are necessary to achieve a better understanding of the subject.

Programs that promote equality to reduce violence are necessary, though maybe never enough, and should be based on a framework of respect and human rights. This is a long process that requires learning to navigate it. Women are learning to set limits, and it is necessary for both men and women to learn to express conflict and seek solutions without violence.

\section{Limitations}

The present study has several limitations. First, since it was not a survey aimed at studying IPV, many questions that could more deeply probe the association of alcohol and drug use with violence are left out, such as knowing with greater accuracy which substances were used during the violent event or events, along with those mentioned above. As 
this was a cross-sectional study, causal relationships cannot be established between the analyzed factors and IPV; only statistical associations are established.

\section{Funding}

None.

\section{Conflict of interests}

The authors declare they have no conflicts of interest.

\section{Acknowledgments}

To the Violence and Substance Use Study Group of INSP/INPRFM for their valuable comments.

\section{REFERENCES}

Barker, G., \& Aguayo, F. (2012). Masculinidades y politicas de equidad de género: Reflexiones a partir de la encuesta IMAGES y una revisión de politicas en Brasil, Chile y México. Rio de Janeiro: Promundo.

Black, M. C., Basile, K. C., Breiding, M. J., Smith, S. G., Walters, M. L., Merrick, M. T., ... Stevens, M. R. (2011). National Intimate Partner and Sexual Violence Survey (NISVS): 2010 Summary Report. Atlanta: National Center for Injury Prevention and Control, Centers for Disease Control and Prevention.

Brighton, R., Moxham, L., \& Traynor, V. (2016). Women and alcohol use disorders: Factors that lead to harm. Journal of Addictions Nursing, 27(3), 205-213. doi: 10.1097/JAN.0000000000000136

Carmo, R., Grams, A., \& Magalhães, T. (2011). Men as victims of intimate partner violence. Journal of Forensic and Legal Medicine, 18(8), 355-359. doi: 10.1016/j.jflm.2011.07.006

Catalano, S. M. (2012). Intimate Partner Violence, 1993-2010. Washington, DC: US Department of Justice, Office of Justice Programs, Bureau of Justice Statistics.

Choo, E. K., Benz, M., Rybarczyk, M., Broderick, K., Linden, J., Boudreaux, E. D., \& Ranney, M. L. (2014). The intersecting roles of violence, gender, and substance use in the emergency department: A research agenda. Academic Emergency Medicine, 21(12), 1447-1452. doi: 10.1111/acem.12525

Coker, A. L., Davis, K. E., Arias, I., Desai, S., Sanderson, M., Brandt, H. M., \& Smith, P. H. (2002). Physical and mental health effects of intimate partner violence for men and women. American Journal of Preventive Medicine, 23(4), 260-268. doi: 10.1016/S0749-3797(02)00514-7

Diario Oficial de la Federación. (2007). Ley general de acceso de las mujeres a una vida libre de violencia - Febrero 1, 2007. México: Diario Oficial de la Federación.

Esquivel-Santoveña, E. E., \& Dixon, L. (2012). Investigating the true rate of physical intimate partner violence: A review of nationally representative surveys. Aggression and Violent Behavior, 17(3), 208-219. doi: 10.1016/j.avb.2012.02.002

Instituto Nacional de Estadística y Geografía [INEGI], \& Instituto Nacional de las Mujeres [INMUJERES]. (2013). Mujeres y hombres en México 2013. México: INEGI.

Instituto Nacional de Estadística y Geografía [INEGI]. (2017). Resultados de la Encuesta Nacional Sobre la Dinámica de las Relaciones en los Hogares (ENDIREH) 2016. Boletin de prensa, Núm. 379/17. Ciudad de México: INEGI. Retrieved from http://www.diputados.gob.mx/sedia/biblio/usieg/comunicados/25ene19/pob_ hog_vivie/6_dinamicadelasrelaciones_090818-6.pdf

Instituto Nacional de Salud Pública [INSP]. (2008). Encuesta Nacional de Adicciones 2008. Cuernavaca, Mor.: CONADIC, INPRFM, INSP. Retrieved from https:// www.insp.mx/images/stories/INSP/EncNacAdi/Docs/ENA08_nacional.pdf

Instituto Nacional de las Mujeres [INMUJERES]. (2008). Violencia en las relaciones de pareja. Resultados de la Encuesta Nacional Sobre la Dinámica de las Relaciones en los Hogares, 2006. México: INMUJERES. Retrieved from http:// cedoc.inmujeres.gob.mx/documentos_download/100924.pdf

Leonard, K. E. (2005). Alcohol and intimate partner violence: When can we say that heavy drinking is a contributing cause of violence? Addiction, 100(4), 422-425. doi: $10.1111 / j .1360-0443.2005 .00994 . x$
Leonard, K. E., \& Blane, H. T. (1992). Alcohol and marital aggression in a national sample of young men. Journal of Interpersonal Violence, 7(1), 19-30. doi: $10.1177 / 088626092007001002$

Lövestad, S., \& Krantz, G. (2012). Men's and women's exposure and perpetration of partner violence: An epidemiological study from Sweden. BMC Public Health, 12(1), 945. doi: 10.1186/1471-2458-12-945

Medina-Mora, M. E., Real, T., Villatoro, J., \& Natera, G. (2013). Las drogas y la salud pública: ¿hacia dónde vamos? Salud Pública de México, 55(1), 67-73. doi: 10.1590/S0036-36342013000100010

Miranda, L., Halperin, D., Limón, F., \& Tuñon, E. (1998). Características de la violencia doméstica y las respuestas de las mujeres en una comunidad rural del municipio de Las Margaritas, Chiapas. Salud Mental, 21(6), 19-26.

Moore, T. M., Elkins, S. R., McNulty, J. K., Kivisto, A. J., \& Handsel, V. A. (2011). Alcohol use and intimate partner violence perpetration among college students: Assessing the temporal association using electronic diary technology. Psychology of Violence, 1(4), 315-328. doi: 10.1037/a0025077

Muñoz, J. M., \& Echeburúa, E. (2016). Diferentes modalidades de violencia en la relación de pareja: Implicaciones para la evaluación psicológica forense en el contexto legal español. Anuario de Psicología Jurídica, 26(1), 2-12. doi: 10.1016/j.apj.2015.10.001

Natera, G. (2017). Restauración de las emociones en mujeres indígenas con parejas que abusan del alcohol. In R. Esteinou \& O. Hansberg (Eds.), Acercamientos multidisciplinario a las emociones (pp. 37-58). México: UNAM.

Natera, G., \& Hernández, D. (2013). La violencia de pareja y su vínculo con el consumo de alcohol y otras drogas. In: C. A. Carrascoza Venegas (Eds.), Aspectos culturales, sociales y preventivos de las adicciones en México (pp. 145-173). México: Consejo Nacional para la Cultura y las Artes.

Natera, G., \& Holmila, M. (1990). El papel de los roles sexuales en la familia y el consumo de alcohol. Una comparación entre México y Finlandia. Salud Mental, 13(3), 20-26.

Natera, G., \& Juárez, F. (2010). Intimate partner violence and its link with depression, alcohol and drug consumption: An epidemiological study in Mexico. In C. Wilkinson, \& R. Room. (Eds), Alcohol and violence, relationships, causality, and policy. Meeting of the Kettil Bruun Society. Australia: KBS.

Natera Rey, G., Juárez García, F., \& Tiburcio Sainz, M. (2004). Validez factorial de una escala de violencia hacia la pareja en una muestra nacional mexicana. Salud Mental, 27(2), 31-38.

O'Leary, K. D., \& Schumacher, J. A. (2003). The association between alcohol use and intimate partner violence: Linear effect, threshold effect, or both? Addictive Behaviors, 28(9), 1575-1585. doi: 10.1016/j.addbeh.2003.08.034

STATA Version 13. (2013). Stata statistical software: Release 13. Texas: StataCorp LP.

Saldívar, G. (2018). Salud mental y violencia en el noviazgo en adolescentes. In R. Guadarrama \& N. Torres (Eds.), Salud mental y conductas de riesgo en el adolescente (pp. 63-84). México: Universidad Autónoma del Estado de México.

Stalans, L. J., \& Ritchie, J. (2008). Relationship of substance use/abuse with psychological and physical intimate partner violence: Variations across living situations. Journal of Family Violence, 23(1), 9-24. doi: 10.1007/s10896-0079125-8

Tryggvesson, K. (2004). The ambiguous excuse: Attributing violence to intoxication-young Swedes about the excuse value of alcohol. Contemporary Drug Problems, 31(2), 231-261. doi: 10.1177/009145090403100204

Villatoro-Velázquez, J., Medina-Mora, M., Fleiz-Bautista, C., Téllez-Rojo, M., Mendoza-Alvarado, L., Romero-Martínez, M., ... Guisa-Cruz, V. (2012). Encuesta Nacional de Adicciones 2011: Reporte de Drogas. México: Instituto Nacional de Psiquiatría Ramón de la Fuente Muñiz, Instituto Nacional de Salud Pública, Secretaría de Salud.

World Health Organization [WHO]. (2005). Estudio multipais de la OMS sobre salud de la mujer y violencia doméstica. Primeros resultados sobre prevalencia, eventos relativos a la salud y respuestas de las mujeres a dicha violencia: Resumen del informe. Ginebra: Organización Munidal de la Salud.

World Health Organization [WHO]. (2017). Violence against women: Key facts. Geneva: World Health Organization. 